\title{
LAND SUBSIDENCE IN EAST CALCUTTA
}

\author{
Dr. Amartya Kumar Bhattacharya ${ }^{1}$, Debasish Kumar ${ }^{2}$ \\ ${ }^{I}$ (Department Of Applied Mechanics, Bengal Engineering And Science University, Shibpur \\ Howrah - 711103, West Bengal) India. \\ ${ }^{2}$ (Department Of Applied Mechanics, Bengal Engineering And Science University, Shibpur \\ Howrah - 711103, West Bengal) India.
}

\begin{abstract}
In this paper two approaches have been mentioned to calculate subsidence. One is based on the linear theory (considering elastic property of the material) and the other on the logarithmic theory. In the linear theory coefficient of volume compressibility (denoted as $m_{v}$ ) indicates the nature of soil towards compression and in the logarithmic theory compression index (denoted as $C_{c}$ ) indicates the same. The top $30 \mathrm{~m}$. of the subsurface soil stratification in Calcutta generally indicates softer clayey soil in the first $15 \mathrm{~m}$. having higher $m_{v}$ values and relatively stiffer clayey soil between $15 \mathrm{~m}$. and $30 \mathrm{~m}$. having lower $m_{v}$ values. Further below the compressibility of the layers diminishes due to increasing overburden pressure also. In the analysis section for subsidence in two localities in Central Calcutta, firstly data of soil characteristics and properties in different layers and change in piezometric level or depth of water table from 1956 to 2000 are represented. Based on these data intergranular pressures for different layers are calculated and finally total subsidence in the said time span is estimated using the linear theory. This comes out to be $0.3299 \mathrm{~m}$ (average) for East Calcutta region from 1956 to 2000 and hence estimated average subsidence rate is $7.50 \mathrm{~mm} /$ year.
\end{abstract}

Keywords: Land Subsidence, Soil Consolidation, Groundwater.

\section{INTRODUCTION}

Analyzing Terzaghi's theory [1] on compressibility of soils and other later developments on this (e.g. Colijn and Potma [2], Taylor [3], Abbot [4], Terzaghi and Peck [5], Roberts [6], Gambolati et al. [7], Bull and Poland [8] etc.), two approaches have been made to calculate subsidence. One is based on the linear theory (considering elastic property of the material) and the other on the logarithmic theory.

According to the linear theory, subsidence is given by

$$
S_{u}=\left(P_{i 2}-P_{i 1}\right) \cdot \frac{Z_{1}}{E}=m_{v} Z_{1}\left(P_{i 2}-P_{i 1}\right)
$$

and according to the logarithmic theory, subsidence is given by

$$
S_{u}=Z_{1} C_{u} \log \left(P_{i 2} / P_{i 1}\right)
$$

where $Z_{l}=$ thickness of the soil layer prior to compression,

$P_{i 1}=$ intergranular pressure when ground water table is at initial piezometric level,

$P_{i 2}=$ increased intergranular pressure when water table is at final piezometric level due to drawdown,

$m_{v}=$ Coefficient of volume compressibility $=$ reciprocal of the compression modulus $E$,

$C_{u}=\frac{C_{c}}{e_{1}+1}, C_{c}$ being called the compression index, slope of the essentially linear portion of $e$ vs $\log P_{i}$ curve and $e_{1}$ being the void ratio of the soil layer prior to compression.

\section{GENERAL STRATIFICATION OF SUBSURFACE SOIL OF CALCUTTA}

The top $30 \mathrm{~m}$. of the subsurface soil strata in Calcutta consists mainly of successive layers of clay, silty clay and clayey silt, and can be subdivided into two horizons based on the relative compressibility of the different strata. The upper clay horizon (top $15 \mathrm{~m}$.) generally consists of softer components, whereas the clay below $15 \mathrm{~m}$ depth, consists of much stiffer materials (Bhattacharya et al. [9]). This stratification is generally referred to as the Normal Calcutta Deposit and is found to exist over most of the study area. A general classification of the Normal Calcutta Deposit along with the $m_{v}$ values after Dastidar and Ghosh [10] is shown in Table 1. A perusal of the Table reveals that the clay layer between $15 \mathrm{~m}$. and $30 \mathrm{~m}$. is relatively stiff as indicated by the low $m_{v}$ value. Further below, the compressibility of the layers will be even less because of the increasing overburden pressure and, therefore, they may not play a significant role in land subsidence. 
Table 1: Stratification of Normal Calcutta Deposit (after Dastidar and Ghosh [10])

\begin{tabular}{|c|c|c|c|}
\hline Stratum & $\begin{array}{c}\text { Depth } \\
(\mathrm{m})\end{array}$ & Description & $\begin{array}{c}\text { Coefficient of volume } \\
\text { compressibility } m_{v} \\
\left(\mathrm{~cm}^{2} / \mathrm{kg}\right)\end{array}$ \\
\hline I & $0-5$ & Firm grey silty clay & 0.014 \\
\hline II & $5-15$ & Soft grey clay with wood stumps & 0.04 \\
\hline III & $15-20$ & Bluish grey clay with kankar & 0.01 \\
\hline IV & $20-25$ & Laminated brown clay, silt & 0.01 \\
\hline V & $25-30$ & Stiff mottled grey and yellow clay with kankar & 0.01 \\
\hline VI & $>30$ & $\begin{array}{c}\text { Mottled silty clay laminated with parting of } \\
\text { golden brown silty sand }\end{array}$ \\
\hline
\end{tabular}

\section{VARIATIONS IN PIEZOMETRIC LEVELS IN SOME PARTS OF EAST CALCUTTA}

\section{Site No 1 : Subsidence Analysis at Tangra Area}

From the piezometric level contour map of Biswas \& Saha[12], initial piezometric surface (above mean sea level) in this area in 1956 is $-1.00 \mathrm{~m}$. Final piezometric surface in April 2000 is $-10.00 \mathrm{~m}$. as obtained from SWID [13] contour map. From SWID [13] April 2000 data of Beliaghata Suracross Lane - Tangra area, depth of water level below ground level is $13.94 \mathrm{~m}$. So in April 1956 the water table was 4.94 m. below G. L.

\section{Site No 2 : Subsidence Analysis at Baguiati Area}

From the piezometric level contour map of Biswas \& Saha [12], initial piezometric surface (above mean sea level) in this area in 1956 is $-0.50 \mathrm{~m}$. Final piezometric surface in April 2000 is $-10.00 \mathrm{~m}$. as obtained from SWID [13] contour map. From SWID [13] April 2000 data of Baguiati area, depth of water level below ground level is $12.13 \mathrm{~m}$. So in April 1956 the water table was $2.63 \mathrm{~m}$. below G. L.

It should be noted that the pre-monsoon month April is chosen as the reference month for comparison and this is also in accordance with the recent literature on land subsidence (Agarwal [11]) which states that land subsidence "occurred in the pre-monsoon period when the water table happened to be the deepest and recharge to groundwater is least or negligible."

\section{ANALYSIS OF SUBSIDENCE IN SOME PARTS OF CENTRAL CALCUTTA}

\section{Site No 1 : Subsidence Analysis at Tangra Area}

The site whose soil profile is described below at Tangra area and lies in the region of East Calcutta mentioned above.

\subsection{SOIL CHARACTERTISTICS AND GROUNDWATER LEVELS}

Table 2: Soil Profile at Tangra area \& Laboratory Test Results

\begin{tabular}{|c|l|c|c|c|}
\hline $\begin{array}{c}\text { Layer (in terms } \\
\text { of depth below } \\
\text { G.L.) }\end{array}$ & \multicolumn{1}{|c|}{ Description } & $\begin{array}{c}\text { Dry } \\
\text { Density } \\
\left(\gamma_{\mathrm{d}}\right) \\
{\left[\mathrm{gm} / \mathrm{cm}^{3}\right]}\end{array}$ & $\begin{array}{c}\text { Sp. } \\
\text { Gr. } \\
(\mathrm{G})\end{array}$ & $\begin{array}{c}\text { Water } \\
\text { Content } \\
(\mathrm{w}) \\
{[\%]}\end{array}$ \\
\hline $0.0-1.80 \mathrm{~m}$. & Filled up soil with brickbats, building refuses, etc. & 1.44 & 2.68 & 30 \\
\hline $1.80-5.85 \mathrm{~m}$. & $\begin{array}{l}\text { Firm, brownish grey, silty clay / clayey silt with } \\
\text { kankars }\end{array}$ & 1.476 & 2.66 & 27 \\
\hline $5.85-13.85 \mathrm{~m}$. & $\begin{array}{l}\text { Soft bluish grey, silty clay to clayey silt with } \\
\text { decomposed wood }\end{array}$ & 1.164 & 2.60 & 41 \\
\hline $13.85-16.35 \mathrm{~m}$. & Stiff bluish grey, silty clay with calcareous nodules & 1.478 & 2.65 & 24 \\
\hline $16.35-18.00 \mathrm{~m}$. & Stiff yellowish / bluish grey laminated clayey silt & 1.523 & 2.68 & 23 \\
\hline $18.00-21.35 \mathrm{~m}$. & Medium brownish grey, fine sand & 1.55 & 2.74 & 24 \\
\hline $21.35-27.45 \mathrm{~m}$. & Brown sandy clay & 1.51 & 2.68 & 32.5 \\
\hline
\end{tabular}


\begin{tabular}{|l|l|}
\hline $27.45-30.50 \mathrm{~m}$. & Brown, fine micaceous sand \\
\hline
\end{tabular} 1.59 2.66 24

The water table was at $4.94 \mathrm{~m}$. below Ground Level in the year 1956 and has gone down to $13.94 \mathrm{~m}$. below Ground Level in April year 2000 in this region.

\subsection{CALCULATION OF INTERGRANULAR PRESSURES OF SOIL LAYERS}

Table 3: Calculation of Intergranular Pressures in the years 1956 and 2000 at Tangra area

\begin{tabular}{|c|c|c|c|c|c|c|c|}
\hline $\begin{array}{c}\text { Depth } \\
{[\mathrm{m} .]}\end{array}$ & $\begin{array}{c}\text { Porosity } \\
\eta=1-\frac{\gamma_{d}}{G \gamma_{w}} \\
{[\%]}\end{array}$ & $\begin{array}{c}\text { Unit wt. of soil } \\
\gamma=(1-\eta) G \gamma_{w}+w \cdot \gamma_{w} \\
{\left[\mathrm{gm} / \mathrm{cm}^{3}\right]}\end{array}$ & $\begin{array}{c}\text { Total } \\
\text { Pressure } \mathrm{P}_{\mathrm{t}} \\
{\left[\mathrm{kg} / \mathrm{cm}^{2}\right]}\end{array}$ & $\begin{array}{c}\mathrm{P}_{\mathrm{h}} \\
\text { at Apr., } \\
1956 \\
\mathrm{P}_{\mathrm{h} 1} \\
{\left[\mathrm{~kg} / \mathrm{cm}^{2}\right]}\end{array}$ & $\begin{array}{c}\mathrm{P}_{\mathrm{i} 1} \\
=\left(\mathrm{P}_{\mathrm{t}}-\mathrm{P}_{\mathrm{h} 1}\right) \\
{\left[\mathrm{kg} / \mathrm{cm}^{2}\right]}\end{array}$ & $\begin{array}{c}\mathrm{P}_{\mathrm{h}} \\
\text { at Apr., } \\
2000 \\
\mathrm{P}_{\mathrm{h} 2} \\
{\left[\mathrm{~kg} / \mathrm{cm}^{2}\right]}\end{array}$ & $\begin{array}{c}\mathrm{P}_{\mathrm{i} 2} \\
=\left(\mathrm{P}_{\mathrm{t}}-\mathrm{P}_{\mathrm{h} 2}\right) \\
{\left[\mathrm{kg} / \mathrm{cm}^{2}\right]}\end{array}$ \\
\hline 1.80 & 46.27 & 1.74 & 0.3132 & 0 & 0.3132 & 0 & 0.3132 \\
\hline 5.85 & 44.51 & 1.746 & 1.0203 & 0.091 & 0.9293 & 0 & 1.0203 \\
\hline 13.85 & 55.23 & 1.574 & 2.2795 & 0.891 & 1.3885 & 0 & 2.2795 \\
\hline 16.35 & 44.23 & 1.718 & 2.709 & 1.141 & 1.568 & 0.206 & 2.468 \\
\hline 18.00 & 43.17 & 1.753 & 2.9983 & 1.306 & 1.6923 & 0.556 & 2.5923 \\
\hline 21.35 & 43.43 & 1.79 & 3.5979 & 1.641 & 1.9569 & 0.806 & 2.8569 \\
\hline 27.45 & 43.66 & 1.835 & 4.7173 & 2.251 & 2.4663 & 1.116 & 3.3663 \\
\hline 30.50 & 40.23 & 1.83 & 5.2754 & 2.556 & 2.7194 & 1.606 & 3.6194 \\
\hline
\end{tabular}

5 .

4.3. CALCUlation OF SUBSIDENCE

Table 4: Calculation of Subsidence at Tangra area with linear theory (from 1956 to 2000)

\begin{tabular}{|c|c|c|c|c|c|c|}
\hline Layer [m.] & $\begin{array}{c}\mathrm{Z} 1 \\
{[\mathrm{~m} .]}\end{array}$ & $\begin{array}{c}\mathrm{Pi} 1 \\
{[\mathrm{~kg} / \mathrm{cm} 2]}\end{array}$ & $\begin{array}{c}\mathrm{Pi} 2 \\
{[\mathrm{~kg} / \mathrm{cm} 2]}\end{array}$ & $\begin{array}{c}\mathrm{Pi} 2- \\
\mathrm{Pi} 1 \\
{[\mathrm{~kg} / \mathrm{cm} 2} \\
]\end{array}$ & $\begin{array}{c}\text { mv values for the } \\
\text { corresponding overburden } \\
\text { pressure (obtained from } \\
\text { the collected data for the } \\
\text { specific pressure range })\end{array}$ & $\begin{array}{c}S_{u}=\left(P_{i 2}-P_{i 1}\right) \cdot m_{v} \\
{[\mathrm{~m} .]}\end{array}$ \\
\hline $0.0-1.80$ & 1.8 & 0.3132 & 0.3132 & 0 & - & 0 \\
\hline $1.80-5.85$ & 4.05 & 0.9293 & 1.0203 & 0.091 & 0.02477 & 0.00913 \\
\hline $5.85-13.85$ & 8.0 & 1.3885 & 2.2795 & 0.891 & 0.02418 & 1.17236 \\
\hline $13.85-16.35$ & 2.5 & 1.568 & 2.468 & 0.9 & 0.01444 & 0.03249 \\
\hline $16.35-18.00$ & 1.65 & 1.6923 & 2.5923 & 0.9 & 0.01016 & 0.01509 \\
\hline $18.00-21.35$ & 3.35 & 1.9569 & 2.8569 & 0.9 & $0.89 \times 10-2$ & 0.02683 \\
\hline $21.35-27.45$ & 6.1 & 2.4663 & 3.3663 & 0.9 & $0.88 \times 10-2$ & 0.04831 \\
\hline $27.45-30.50$ & 3.05 & 2.7194 & 3.6194 & 0.9 & $0.89 \times 10-2$ & 0.02443 \\
\hline
\end{tabular}

From 1956 to 2000, i.e., in 44 years subsidence in this area is around $32.864 \mathrm{~cm}$. and hence subsidence rate is $0.747 \mathrm{~cm} . / y e a r$ or $7.47 \mathrm{~mm} /$ year. 


\section{Site No 2 : Subsidence Analysis at Baguiati Area}

The site whose soil profile is described below is at Baguiati area and lies in the region of East Calcutta mentioned above.

\subsection{SOIL CHARACTERTISTICS AND GROUNDWATER LEVELS}

Table 5: Soil Profile at Baguiati area \& Laboratory Test Results

\begin{tabular}{|c|l|c|c|c|}
\hline $\begin{array}{c}\text { Layer (in terms } \\
\text { of depth below } \\
\text { G.L. })\end{array}$ & \multicolumn{1}{|c|}{ Description } & $\begin{array}{c}\text { Dry } \\
\text { Density } \\
\left(\gamma_{\mathrm{d}}\right) \\
{\left[\mathrm{gm} / \mathrm{cm}^{3}\right]}\end{array}$ & $\begin{array}{c}\text { Sp. } \\
\mathrm{Gr} .\end{array}$ & $\begin{array}{c}\text { Water } \\
\text { Content } \\
(\mathrm{w}) \\
{[\%]}\end{array}$ \\
\hline $0.0-0.60 \mathrm{~m}$. & $\begin{array}{l}\text { Top fill of soft earth mixed with brick packs, ash, } \\
\text { grass roots, rubbish, loose sand, etc. }\end{array}$ & 1.31 & 2.61 & 39.52 \\
\hline $0.60-2.50 \mathrm{~m}$. & $\begin{array}{l}\text { Soft/ medium brownish-grey/ greyish/ dark grey } \\
\text { silty clay/ clayey silt with traces of decomposed } \\
\text { wood \& organic matter. Occasionally fine sand was } \\
\text { also observed; consistency varying throughout the } \\
\text { layer. }\end{array}$ & 1.37 & 2.62 & 33.3 \\
\hline $2.50-3.20 \mathrm{~m}$. & $\begin{array}{l}\text { Very soft greyish/ dark grey silty clay with high } \\
\text { percentage of decomposed wood }\end{array}$ & 0.66 & 2.67 & 79.85 \\
\hline $3.20-4.00 \mathrm{~m}$. & $\begin{array}{l}\text { Soft brownish-grey sandy silty clay/ sandy clayey } \\
\text { silt with traces of mica }\end{array}$ & 1.39 & 2.63 & 32.57 \\
\hline $4.00-15.50 \mathrm{~m}$. & $\begin{array}{l}\text { Soft/ medium greyish silty clay/ clayey silt with } \\
\text { little traces of decomposed wood \& traces of fine } \\
\text { sandy laminations. }\end{array}$ & 1.275 & 2.64 & 34.26 \\
\hline $15.50-19.50 \mathrm{~m}$. & $\begin{array}{l}\text { Stiff/ very stiff bluish/ mottled yellowish sandy/ } \\
\text { silty clay/ sandy clayey silt with kankar \& traces of } \\
\text { mica }\end{array}$ & 1.33 & 2.65 & 35.06 \\
\hline $19.50-21.75 \mathrm{~m}$. & $\begin{array}{l}\text { Medium/ dense bluish-grey/ grey sandy silt/ silty } \\
\text { sand with ferrogeneous spots \& traces of clay }\end{array}$ & 1.44 & 2.66 & 28.34 \\
\hline $21.75-25.10 \mathrm{~m}$. & $\begin{array}{l}\text { Very stiff brownish-grey silty clay/ sandy silty clay } \\
\text { with ferrogeneous spots \& traces of mica }\end{array}$ & 1.45 & 2.69 & 27 \\
\hline $25.10-30.00 \mathrm{~m}$. & Grey and brown hard sticky clay & 1.49 & 2.67 & 29 \\
\hline
\end{tabular}

From SWID [13] April 2000 data of Baguiati area, depth of water level below ground level is $12.13 \mathrm{~m}$ and in April 1956 the water table was $2.63 \mathrm{~m}$ below $\mathrm{G}$. L.

\subsection{CALCULATION OF INTERGRANULAR PRESSURES OF SOIL LAYERS}

Table 6: Calculation of Intergranular Pressures in the years 1956 and 2000 at Baguiati area

\begin{tabular}{|c|c|c|c|c|c|c|c|}
\hline $\begin{array}{c}\text { Depth } \\
{[\mathrm{m} .]}\end{array}$ & $\begin{array}{c}\text { Porosity } \\
\eta=1-\frac{\gamma_{d}}{G \gamma_{w}} \\
{[\%]}\end{array}$ & $\begin{array}{c}\text { Unit wt. of soil } \\
\gamma=(1-\eta) G \gamma_{w}+w \cdot \gamma_{w} \\
{\left[\mathrm{gm} / \mathrm{cm}^{3}\right]}\end{array}$ & $\begin{array}{c}\text { Total } \\
\text { Pressure } \mathrm{P}_{\mathrm{t}} \\
{\left[\mathrm{kg} / \mathrm{cm}^{2}\right]}\end{array}$ & $\begin{array}{c}\mathrm{P}_{\mathrm{h}} \\
\text { at Apr., } \\
1956 \\
\mathrm{P}_{\mathrm{h} 1} \\
{\left[\mathrm{~kg} / \mathrm{cm}^{2}\right]}\end{array}$ & $\begin{array}{c}\mathrm{P}_{\mathrm{i} 1} \\
=\left(\mathrm{P}_{\mathrm{t}}-\mathrm{P}_{\mathrm{h} 1}\right) \\
{\left[\mathrm{kg} / \mathrm{cm}^{2}\right]}\end{array}$ & $\begin{array}{c}\mathrm{P}_{\mathrm{h}} \\
\text { at Apr., } \\
2000 \\
\mathrm{P}_{\mathrm{h} 2} \\
{\left[\mathrm{~kg} / \mathrm{cm}^{2}\right]}\end{array}$ & $\begin{array}{c}\mathrm{P}_{\mathrm{i} 2} \\
=\left(\mathrm{P}_{\mathrm{t}}-\mathrm{P}_{\mathrm{h} 2}\right) \\
{\left[\mathrm{kg} / \mathrm{cm}^{2}\right]}\end{array}$ \\
\hline 0.60 & 49.81 & 1.7052 & 0.1023 & 0 & 0.1023 & 0 & 0.1023 \\
\hline 2.50 & 47.71 & 1.703 & 0.4259 & 0 & 0.4259 & 0 & 0.4259 \\
\hline 3.20 & 75.28 & 1.4585 & 0.528 & 0.057 & 0.471 & 0 & 0.528 \\
\hline 4.00 & 47.15 & 1.7157 & 0.6652 & 0.137 & 0.5282 & 0 & 0.6652 \\
\hline 15.50 & 51.70 & 1.6176 & 2.5255 & 1.287 & 1.2385 & 0.337 & 2.1885 \\
\hline
\end{tabular}




\begin{tabular}{|l|c|c|c|c|c|c|c|}
\hline 19.50 & 49.81 & 1.6806 & 3.1977 & 1.687 & 1.5107 & 0.737 & 2.4607 \\
\hline 21.75 & 45.86 & 1.7234 & 3.5855 & 1.912 & 1.6735 & 0.962 & 2.6235 \\
\hline 25.10 & 46.10 & 1.72 & 4.1617 & 2.247 & 1.9147 & 1.297 & 2.8647 \\
\hline 30.00 & 44.19 & 1.78 & 5.0339 & 2.737 & 2.2969 & 1.787 & 3.2469 \\
\hline
\end{tabular}

\subsection{CALCULATION OF SUBSIDENCE}

Table 7: Calculation of Subsidence at Baguiati area with linear theory (from 1956 to 2000)

\begin{tabular}{|c|c|c|c|c|c|c|}
\hline Layer [m.] & $\begin{array}{c}\mathrm{Z} 1 \\
{[\mathrm{~m} .]}\end{array}$ & $\begin{array}{c}\mathrm{Pi} 1 \\
{[\mathrm{~kg} / \mathrm{cm} 2]}\end{array}$ & $\begin{array}{c}\mathrm{Pi} 2 \\
{[\mathrm{~kg} / \mathrm{cm} 2]}\end{array}$ & $\begin{array}{c}\mathrm{Pi} 2-\mathrm{Pi} 1 \\
{[\mathrm{~kg} / \mathrm{cm} 2]}\end{array}$ & $\begin{array}{c}\mathrm{m}_{\mathrm{v}} \text { values for the } \\
\text { corresponding } \\
\text { overburden pressure } \\
\text { (obtained from the } \\
\text { collected data for the } \\
\text { specific pressure range) }\end{array}$ & $\begin{array}{c}S_{u}=\left(P_{i 2}-P_{i 1}\right) \cdot m_{v} \cdot Z_{1} \\
{[\mathrm{~m} .]}\end{array}$ \\
\hline $0.0-0.60$ & 0.6 & 0.1023 & 0.1023 & 0 & - & 0 \\
\hline $0.60-2.50$ & 1.9 & 0.4259 & 0.4259 & 0 & $3.20 \times 10-2$ & 0 \\
\hline $2.50-3.20$ & 0.7 & 0.471 & 0.528 & 0.057 & $4.48 \times 10-2$ & 0.00179 \\
\hline $3.20-4.00$ & 0.8 & 0.5282 & 0.6652 & 0.137 & $1.92 \times 10-2$ & 0.00210 \\
\hline $4.00-15.50$ & 11.5 & 1.2385 & 2.1885 & 0.95 & $1.36 \times 10-2$ & 0.14858 \\
\hline $15.50-19.50$ & 4 & 1.5107 & 2.4607 & 0.95 & $0.88 \times 10-2$ & 0.03344 \\
\hline $19.50-21.75$ & 2.25 & 1.6735 & 2.6235 & 0.95 & $0.85 \times 10-2$ & 0.01817 \\
\hline $21.75-25.10$ & 3.35 & 1.9147 & 2.8647 & 0.95 & $2.50 \times 10-3$ & 0.07956 \\
\hline $25.10-30.00$ & 4.9 & 2.2969 & 3.2469 & 0.95 & $1.02 \times 10-2$ & 0.04748 \\
\hline & & & & & & 0.33112 \\
\hline
\end{tabular}

From 1956 to 2000, i.e., in 44 years subsidence in this area is around $33.112 \mathrm{~cm}$. and hence subsidence rate is $0.7525 \mathrm{~cm} . /$ year or $7.525 \mathrm{~mm} . /$ year.

\section{CONCLUSION}

The total estimated subsidence near Tangra area is 32.864 c.m. from 1956 to 2000, i.e. in 44 years. Hence estimated subsidence rate is $7.47 \mathrm{~mm} /$ year. The total estimated subsidence at Baguiati is $33.112 \mathrm{c.m}$. from 1956 to 2000, i.e. in 44 years. Hence estimated subsidence rate is $7.525 \mathrm{~mm} /$ year. Since this entire region is more or less uniformly subsiding, no visible ground crack or collapse of building or structure has been reported till now, the average subsidence rate (without considering rebound or swelling which may be a maximum of $10 \%$ ) is estimated to be $7.50 \mathrm{~mm} / \mathrm{year}$ for a average decline of piezometric level by $9.25 \mathrm{~m}$.

\section{REFERENCES}

[1] K.TERZAGHI : Theoretical Soil Mechanics, Wiley, New York, 1943.

[2] P.J.COLIJN and J.POTMA : Weg-en Waterbouwkunde, I, Groundmechanica, Kosmos, Amsterdam, 1944.

[3] D.W.TAYLOR : Fundamentals of Soil Mechanics, John Wiley and Sons, Inc., New York, 1958.

[4] M.B.ABBOTT : One-dimensional consolidation of multi-layered soils, Geotechnique, 1960, Vol. 10, pp. 151 - 165. 
[5] K.TERZAGHI and R.B.PECK: Soil Mechanics in Engineering Practice, John Wiley and Sons, Inc., New York, 1967.

[6] J.E.ROBERTS: Sand compression as a factor in oil field subsidence, Proc. Tokyo Symp. on Land Subsidence, IASHUNESCO, 1969, pp. $368-376$.

[7] G.GAMBOLATI and R.A.FREEZE: Mathematical simulation of the subsidence of Venice. 1. Results, Water Resources Research, 1974, Vol. 10, pp. 563 - 577.

[8] W.B.BULL and J.F.POLAND: Land subsidence due to groundwater withdrawal in the Los Banos - Kettleman City area, California. Part 3. Interrelations of water-level change, change in aquifer-system thickness, and subsidence, $U$. $S$. Geological Survey Prof. Paper, 1975, 437 -G, 62 pp.

[9] A.K. BHATTACHARYA, S.RAY, P.K.MAJUMDAR and P.K.SENGUPTA: Hydrogeology of Calcutta, Proceedings, International Conference - Water and Wastewater: Perspectives of Developing countries, 11-13 December, 2002, New Delhi, pp. $567-571$.

[10] A.G.DASTIDAR and P.K.GHOSH: A study of subsoil conditions of Calcutta, Journal of the Civil Engineering Division, Institution of Engineers (India), 1967, Vol. 48(3), pp. 692 - 714.

[11] C.SAGARWAL: Geomorphological Study for Land Subsidence in a part of District Farrukhabad, Hydrology Journal, 2002, Vol. 25(1), pp. $61-68$.

[12] A.B.BISWAS and A. K. SAHA: "Environmental hazards of the recession of piezometric surface of the groundwater under Calcutta." Proceedings of Indian National Science Academy 51A (3), pp.610 - 621.

[13] STATE WATER INVESTIGATION DIRECTORATE (SWID), West Bengal: Contour Map of Piezometric Surface in Kolkata in the Pre-monsoon, 2000 and Ground Water Levels in different localities of Kolkata in April 2000. 